\title{
The Political Codex project of Joseph II $^{*}$
}

\section{STEPHAN WAGNER}

\section{Introduction}

Besides the well known legislative work in the fields of private law and criminal law also the public law came into view under Joseph II when a so-called Political Codex (Politischer Kodex) was for the first time seriously projected in the 1780ies. ${ }^{1}$

This Political Codex was intended to be a legislative counterpart to the codifications in private and criminal law. The work started about 1780 and lasted with shorter and longer interruptions until 1818, a year after the death of Joseph von Sonnenfels (1733-1817), who had been the mastermind and spin-doctor of the Political Codex project. $^{2}$ The Political Codex did never appear, it did not even reach the state of an elaborated draft. According to the surviving schemes its proposed structure was mirroring Sonnenfels' doctrines and its content was meant to cover the whole of public administration, i. e. anything which has not been dealt with in the civil or criminal code. ${ }^{3}$

This article focuses on the early period of this project under Joseph II and the Emperor's impact on its progress. After a look back to Maria Theresa (see II) follows a thorough examination of the set up of the commission for the elaboration of the Political Codex in 1781 (see III.1). Then the first drafts of this commission are analysed (see III.2) and its decline in the reign of Joseph II (see III.3). Finally the article concludes with some remarks about the reasons for the failure of the Political Codex project in this period (see IV).

The present study of this project is based as far as possible on the official documents in the Haus-, Hof- und Staatsarchiv (HHStA) in Vienna, mainly the protocols of the Council of

* This article bases on a presentation given on 23 September 2011 in Edmonton at the International Conference: New Perspectives on the Austrian Enlightenment at the Wirth Institute for Austrian and Central European Studies, University of Alberta.

1 Stephan Wagner, Der Politische Kodex. Die Kodifikationsarbeiten auf dem Gebiet des öfentlichen Rechts in Österreich 1780-1818, Berlin 2004.

2 See Karl-Heinz Osterloh, Joseph von Sonnenfels und die österreichische Reformbewegung im Zeitalter des aufgeklärten Absolutismus. Eine Studie zum Zusammenhang von Kameralwissenschaft und Verwaltungspraxis, Lübeck-Hamburg 1970, p. 204-234; Werner Ogris, Joseph von Sonnenfels als Rechtsreformer, in: Helmut Reinalter (ed.), Joseph von Sonnenfels, Wien 1988, p. 11-95, 48-51; Simon Karstens, Lehrer - Schriftsteller - Staatsreformer. Die Karriere des Joseph von Sonnenfels (1733-1817), Wien-Köln-Weimar 2011, p. 446-461: Unfortunately with some inaccuracies, see the critical review by Stephan Wagner, Zeitschrift der Savigny-Stiftung für Rechtsgeschichte, Germanistische Abteilung 129, 2012, p. 609-615, 611 ff.

3 See below, n. 47 and n. 34 ff. 
State (Staatsratsprotokolle: StR-Prot.). ${ }^{4}$ The pertinent documents themselves (Staatsratsakten) have been destroyed in the Second World War and are not available any more. This gap can be filled in a very limited way by the respective votes of the State Chancellor Kaunitz (Kaunitz-Voten zum Staatsrat: StR-Kaunitz). ${ }^{5}$ In addition supplying source material is sometimes quoted in the older secondary literature such as Hock/Bidermann ${ }^{6}$ and Adler ${ }^{7}$ giving some helpful information, too.

The documents in the Allgemeines Verwaltungsarchiv (AVA) in Vienna dealing with the Political Codex do still exist, ${ }^{8}$ although severely damaged by the Justizpalastbrand of 15 July 1927, ${ }^{9}$ but they cover only the later period beginning with the reinforcement of this project by Leopold II in 1790/91 until the responsible commission's final dissolution in $1818 .{ }^{10}$ However, in these later documents Sonnenfels is in retrospective telling his point of view about the early events under Joseph II and even under Maria Theresa.

\section{First steps under Maria Theresa}

The idea to create a codification on the field of public law emerged already in the reign of Maria Theresa, but it remains

4 Therefore first the respective index (Index zu den Staatsratsakten: StR-Index) of the years $1778 \mathrm{ff}$. has been checked for key-words. Through the file number found in the index, as for instance „252 ex 1781“, it is possible to seize the corresponding entry in the protocols: There are noted the ingoing and outgoing of the respective record, its exact matter as well as the wording of the imperial decision. For details, see S. Wagne r, Der politische Kodex, p. 19-20, 527-529.

5 The Kaunitz-Voten can also be inferred from the file number already mentioned in n. 4. Besides they do also have a serial number, which in the following is always quoted in the first place ahead of the respective file number in brackets, e.g. in the example given in n. 4: „Votum 20 de 1781 (StR 252 ex 1781)“.

6 Carl Freiherr von Hock - Hermann I. Bidermann, Der österreichische Staatsrath (1760-1848). Eine geschichtliche Studie, Wien 1879.

7 Sigmund Adler, Die politische Gesetzgebung in ibren geschichtlichen Beziehungen zum allgemeinen bürgerlichen Gesetzbuche, in: Wiener Juristische Gesellschaft (ed.), Festschrift zur Jahrhundertfeier des ABGB, vol. I, Wien 1911, p. 83-145.

8 Allgemeines Verwaltungsarchiv (AVA) Wien, Hofkanzlei, III A 3, Karton 310-314 and Karton 315; see S. Wagner, Der politische Kodex, p. 20-23, 527. - In addition some copies made for the commission's later president Count Johann Rudolph von Chotek can be found in the Státní oblastní Archiv Prague (SOA) Praha, Rodinný archiv Chotků 141.

9 For the condition of these documents (so-called Brandakten), see the photographs in S. WAGner, Der politische Kodex, p. 521-526. - For the Justizpalastbrand, see Gerhard Botz, Der „15. Juli 1927“, seine Ursachen und Folgen, in: Ludwig Jelicka - Rudolf Neck (edd.), Österreich 1927 bis 1938, München 1973, p. 31-42; Rudolf Neck - Adam Wandruszka (edd.), Die Ereignisse des 15. Juli 1927, München 1979; especially Gerhard Botz, Die „Juli-Demonstranten“, ibre Motive und die quantifizierbaren Ursachen des „15. Juli 1927“, in: ibidem, p. 17-59.

10 For this period, see also Theodor Exel, Die Codification des öffentlichen Rechtes und die Reform des Registratur- und Archivwesens in Österreich, Wien 1875, p. 3-16. 
uncertain, since when this issue was in fact seriously projected. Adler's assumption that this happened as early as in $1753,{ }^{11}$ appears rather doubtful, in particular because he cannot produce any evidence, although he still had all relevant sources at his hands for his treatise in 1911. In addition Osterloh emphasizes with reason, that only the administrative reforms in 1760-1761, largely inspired by Kaunitz, ${ }^{12}$ set the stage for a codification of public law. ${ }^{13}$

As far as known by present research the first actual evidence of codifying dispositions in public law dates from 1768, that means remarkably from the same time, when the completed drafts for a civil code, the Codex Theresianus, ${ }^{14}$ and a criminal code, the Constitutio Criminalis Theresiana,${ }^{15}$ were waiting for the respective sanction by Maria Theresa.

On 22 March 1768 the Empress decreed in a Handbillett to Count Rudolph Chotek (dealing with sacred history for school instruction), that the Hofkanzlei should accomplish among others the following task: To procure from the Länderstellen short excerpts of all existing regulations in Publicis et Politicis, to check their usefulness, assessing in particular, which regulations could be generally applied in all provinces and which only specially in single provinces, and finally to publish a collection of all regulations for each province. ${ }^{16}$

11 S. Aduer, Die politische Gesetzgebung, p. 90.

12 For these reforms, see Franz A. J. SzAво, Kaunitz and enlightened absolutism 1753-1780, Cambridge 1994, p. 83-99, 353.

13 K.-H. Osterloh, Sonnenfels, p. 205, 28; S. Wagner, Der politische Kodex, p. 24-26.

14 The Codex Theresianus has never been sanctioned, see Philipp Harras Ritter von Harrasowsky, Geschichte der Codification des österreichischen Civilrechtes, Wien 1868, p. 121-125; IDEM (ed.), Der Codex Theresianus und seine Umarbeitungen I, Wien 1883, Einleitung, p. 8-13; Leopold PfafF Franz Hofmann, Commentar zum österreichischen ABGB I/1, Wien 1877, p. 13-17; C. von Hock - H. Bidermann, Der österreichische Staatsrath, p. 43-44; M. Friedrich von MaAsburg, Gutachtliche Äußerung des österreichischen Staatsrathes über den von der Compilationscommission im Entwurfe vorgelegten Codex Theresianus civilis, Allgemeine österreichische Gerichts-Zeitung 32, 1881, p. 209210, 213-214, 217-218; Hans von Voltelini, Der Codex Theresianus im österreichischen Staatsrat, in: Wiener Juristische Gesellschaft (ed.), Festschrift zur Jahrhundertfeier des ABGB I, p. 33-82; F. Szabo, Kaunitz, p. 181-183.

15 The Constitutio Criminalis Theresiana, sanctioned on 31 December 1768, came finally into force on 1 July 1770 after some delay due to Kaunitz' objections, see C. von Hock - H. Bidermann, Der österreichische Staatsrath, p. 42-43; M. Friedrich von MAasburg, Zur Entstehungsgeschichte der Theresianischen Halsgerichtsordnung, mit besonderer Rücksicht auf das im Artikel 58 derselben behandelte crimen magiae vel sortilegii, Wien 1880, p. 17-18, 59-60; Hugo Hoegel, Geschichte des Österreichischen Strafrechtes in Verbindung mit einer Erläuterung seiner grundsätzlichen Bestimmungen I, Wien 1904, p. 65-66, 72; Hermann Conrad, Zu den geistigen Grundlagen der Strafrechtsreform Josephs II. (1780-1788), in: Hans Welzel and others (edd.), Festschrift für Hellmuth von Weber, Bonn 1963, p. 56-74, 58; F. Szaвo, Kaunitz, p. 183-185.

16 Haus-, Hof- und Staatsarchiv (HHStA) Wien, Staatsratsprotokolle (weiter StR-Prot.) 1768/I (vol. 27), 24 ex 1768, Curr. Kern der Biblischen Geschichte alten Testaments, so von Hofe herabgelanget ist: 
With respect to the preceding deliberations in the Staatsrat ${ }^{17}$ also Kaunitz' corresponding vote of 17 March 1768 is not revealing any further. ${ }^{18}$ But Adler, who was still able to consult the Staatsratsakten for his treatise, gives some information concerning the votes of Stupan and Borié. ${ }^{19}$ According to Adler the Empress adopted chiefly the reasoning of Blümegen's vote and his distinction between political regulations, which cannot be standardized due to constitutional differences (,die auch wegen der verschiedenen Verfassungen nicht gleichgemacht werden können"), on the one hand and such which can be universalized, on the other hand. The Empress' order,

„Billet an Gr. Rud. Chotek ... Und gleichwie Ich das in Nicht-Befolgung meiner einmal ertheilten Befeble bestehende Hauptgebrechen allenthalben wirksam behoben wissen will; So hat die Canzley von den Länderstellen einen kurzen Auszug aller wesentlichen noch bestehenden allgemeinen Anordnungen in Publicis et Politicis abzufordern, und nach deren Einlangung die Combination zu machen, welche Anordnungen sich auf alle Länder universalisiren lassen, und welche nur specialiter für dieses oder jenes Land taugen, damit hernach die Gesätze und Ordnungen eines jeden Landes zusammengefasset, zum Druck befördert und zum nutzbaren Gebrauch allgemein kundgemacht werden mögen. Und da in den Preußisch-Schlesischen Patenten und Anordnungen vielleicht dort und da etwas gutes anzutreffen seyn dürfte, so sich auf alle, oder doch einige deutsche Erbländer schicken könnte; so wird von Seiten der Canzley in diesem Werk auch darauf zu reflectiren seyn." See also S. Adler, Die politische Gesetzgebung, p. 90; K.-H. Оsтerloh, Sonnenfels, p. 205.

17 HHStA Wien, Staatsrat Abschriften (weiter StR-Abschriften), Karton 1 (1761-1770) does not contain any corresponding manuscript copy.

18 HHStA Wien, Kaunitz-Voten zum Staatsrat (weiter StR-Kaunitz), Karton 1 (1767-1770), Votum de 1768 (StR 24 ex 1768), Kern der Biblischen Geschichte altes Testaments 1768 - Nebst beygelegten 4 To mis der Samlung der Preußischen Patenten: „ich bin mit vorstehenden Votis vollkommen verstanden."

19 S. Adler, Die politische Gesetzgebung, p. 91 n. 15: „Freiherr v. Stupan erinnert, er habe schon in seinem früheren Votum erwähnt, daß er eine sechsbändige Sammlung preußischer Gesetze samt Register besitze. Er besitze überdies auch z wei preußische Gesetzentwürfe, nämlich das Projekt des Codicis Fridericiani Marchici 'wie alle Prozesse in einem Jahr durch 3 Instanzen zu Ende gebracht werden sollen und möchten', in quarto, de anno 1749, wie auch das Projekt des Corpus iuris Fridericiani, de anno 1750. - In allen diesen Sammlungen kommen verschiedene gute Satzungen vor, jedoch finde ich nichts solches, worauf in Ibro Majestät Erbländer nicht vorlängst, oder in den letzten Zeiten fürgedacht worden ist, in so weit sich derlei Satzungen sich allhier schicken.' - ... v. Stupan meint auch, der Codex Austriacus enthalte vielleicht noch bessere Anordnungen. Der niederösterreichische Regierungskanzler v. Pöck habe sich schon vor einigen Jahren zur Fortsetzung des Werkes angeboten, könne aber vermutlich durch andere Amtsgeschäfte verhindert, damit nicht fertig werden. Bei der Arbeit sei große Vorsicht nötig, damit nur wirklich geltende Anordnungen, nicht etwa auch abgeänderte oder aufgehobene Aufnahme finden. Es sollten auch die Verordnungen für die böhmischen, die inner-, ober- und vorderösterreichischen Länder dem Nachtrag eingeschaltet werden. - Staatsrat Freiherr von Borié meint, Österreich habe die preußischen Patente und Ordnungen nicht nötig, Österreich fehle es nicht an guten Ordnungen. 'Diese übertreffen wabrhaftig die anderer Länder. Es fehlt aber leider an der Exekution.' Der Verordnungen seien zu viele und sie würden zu oft abgeändert. Es müßten also diese zablreichen Gesetze in wenige zusammengefaßt werden. Wenn dies stückweise geschieht, so ist die Vollendung der Arbeit desto eher zu hoffen. Das hindere vorerst nicht die Mandate zu sammeln und aus ibnen einen kurzen Auszug zu machen, der für den Gebrauch sebr nützlich wäre." 
that also the corresponding legislation of Prussian-Silesia had to be reviewed for useful ideas, could be traced back to Blümegen as well. ${ }^{20}$

Particularly for this reason the conclusion appears obvious, that not only a mere law collection was projected, that means a compilation of the present regulations, but rather a codification, for which the thoughts and solutions of foreign legislation should be summoned too. $^{21}$

As the minutes of 26 March 1791 harshly assess in retrospective, the outcome of this work from 1768 until 1780 shall only have been a „shapeless bulk of volumes" (unförmliches Gebäufe von Bänden) with an „unserviceable collection“ (unbrauchbare Sammlung). ${ }^{22}$

For the period up to and including 1780 no further first-hand evidence in the sources has been known so far. ${ }^{23}$

Sonnenfels himself, however, declares about 30 years later - in the draft of his report of 21 November $1808^{24}$ as well as in his report of 12 August $1811^{25}$-, that he was promoted by Maria Theresa to be Hofrat at the Hofkanzlei for the Political Codex project in $1778 .{ }^{26}$ According to the statements in Sonnenfels' promemo-

20 S. Adler, Die politische Gesetzgebung, p. 91-92.

21 Ibidem, p. 91; K.-H. Osterloh, Sonnenfels, p. 205.

22 Minutes of 26 March 1791, fol. 14r, ed. by S. WAGNER, Der politische Kodex, appendix 2, p. 245-256, 246: , daß man ... sich bey der Vollstreckung auf eine blosse mechanische Sammlung beschränkte. Die ganze Frucht einer durch zwölfJahre fortgesetzten Arbeit war ein unforrmliches Gehäufe von Bänden, welches von Seite der Wabl und Zusammenstellung der darin enthaltenen Verordnungen sich auch nicbt durch das geringste Verdienst auszeichnet, ungeachtet der Inhalt in den Registraturen von Böhmen, Mäbren und Schlesien durch einen eigens dazu abgesandten Konzipisten aufgesuchet worden. Diese für sich selbst unbrauchbare Sammlung ...."For these minutes, see S. WAGner, ibidem, p. 55-60, 56. See also S. Adler, Die politische Gesetzgebung, p. 92; K.-H. Oster Loh, Sonnenfels, p. 205-206.

23 Especially for the years $1778-1780$ there is no file number or entry in the respective StR-Index (see above, n. 4) relative to the start up of the Political Codex project. For details, see S. WAGner, Der politische Kodex, p. 31 n. 1.

24 Without specification of the year 1778, the final version of Sonnenfels' report of 21 November 1808, fol. 2r-v, ed. by S. WAGNER, Der politische Kodex, appendix 16, p. 354-389, 355: „... da die höchstselige Fürstinn mich eigentlich, um eine politische Gesetzsammlung zu bearbeiten zum Hofrathe der Hofkanzley beforderte." - With specification of the year 1778, the draft of this report, [fol. 2r], ibidem, p. 355 n. 93: „.. da der Vorschlag zu einer systematischen Sammlung der politischen Gesetze zuerst von mir kam, und ich von der höchstseligen Maria Theresia eigentlich mit der Bestimmung, diese Sammlung zu bearbeiten, bereits im Jahre 1778 zum Hofrathe der Hofkanzley befördert wurde." - For this report, see S. WAGNER, ibidem, p. 144-163.

25 Sonnenfels' report of 12 August 1811, fol. 679v, ed. by S. WAGNER, Der politische Kodex, appendix 31, p. 460-464, 463: „Übrigens könne er, Vicepräsident, nicht umbin, beyzurücken: er sey einiger Massen berechtiget, die Idee eines politischen Codex als die seinige zu betrachten: der vorzüglichste Anstoß zu einem solchen Werke sey von ibm gekommen, und er dieses Werkes wegen im Jahre 1778 als Hofrath zur Kanzley versetzt worden." For this report, see S. WAGNER, ibidem, p. 184-186.

26 For Sonnenfels' actual promotion, see S. Karstens, Sonnenfels, p. 351. 
ria of 7 April $1790^{27}$ and the minutes of 26 March $1791^{28}$ he actually submitted a first proposal (erster Vorschlag) even in Maria Theresa's lifetime in 1780.

Karstens thus has to get credit for his recent discovery of two manuscript copies dealing with this issue in $1780 .{ }^{29}$ The first can be identified as a copy of Sonnenfels' first proposal (erster Vorschlag) to Maria Theresa for the creation of a Political Codex, especially since it does contain a passage, ${ }^{30}$ which in later documents has been almost literally quoted as an excerpt from the very first proposal of $1780 .{ }^{31}$

In this first proposal of 1780 Sonnenfels refers to the Empress' former order (of 1768) to collect all laws and regulations in Politicis and Publicis. ${ }^{32}$ But instead of a mere law collection Sonnenfels does suggest the elaboration of a Political Codex equivalent to the criminal and civil code. ${ }^{33}$ Thus this code should contain every subject-matter which has not been dealt with within the criminal and civil code, namely which is not part of the judicial office but of the public administration. ${ }^{34}$

27 Sonnenfels' promemoria of 7 April 1790, fol. 135r-v, ed. by S. WAgner, Der politische Kodex, appendix 1, p. 235-244, 236-237. For this promemoria, see S. WAGNER, ibidem, p. 44-53, 47-48.

28 Minutes of 26 March 1791, fol. 14v-15r, ed. by S. WAGner, Der politische Kodex, appendix 2, p. 246247. See S. Wagner, ibidem, p. 56.

29 HHStA Wien, Familienkorrespondenz A, Karton 26, fol. 38r-41v and fol. 44r-46v, see S. KarsTENs, Sonnenfels, p. 447 n. 2311. Although these copies do neither contain a specific date nor a signature, they can be dated to 1780 and attributed to Sonnenfels' authorship for the following reasons. The first manuscript, fol. 39r refers to ,meine Berufsverwendung, und das seit 17 Jabren bekleidete politische Lehramt": Sonnenfels became professor for Polizey- und Cameral-Wissenschaften in 1763, cf. S. Karstens, ibidem, p. 69-78. Relating to the first, the second manuscript, fol. $44 \mathrm{v}$ refers to the Political Codex as a project deserving to bear the glorious name of the best princess: ,... durch den vorgesetzten glorwürdigen Namen der besten Monarchinn verherrlicht $z u$ werden würdig“.

30 HHStA Wien, Familienkorrespondenz A, Karton 26, fol. 38v, 43r: „So wie im Gegentheil nichts so sehr die Kraft einer Verwaltung beweist, nichts zuverlässiger von dem Glücke der Bürger zeugt, als Einstimmigkeit in Grundsätzen, von welcher die Uebereinstimmung in Veranstaltungen und Entscheidungen, die Gleichformigkeit in den Handlungen abhängt; wo kein auf das Allgemeine sich beziehender Gegenstand dem Ungefähr oder der Privatabsicht überlassen, wo jedes besondere Gesetz nach dem allgemeinen Ziele hingerichtet ist, jede einzelne Vorsehung einen abgepaßten Theil des Ganzen ausmacht, jede einzelne Handlung, wenn ich so sagen darf, in ein vorgezeichnetes Geleis gelenkt wird, worinnen sie zu desto sicherer Befestigung des angenommenen Hauptplanes, zu desto gewisserer Erreichung des gemeinschaftlichen Zwecks laufen muß."

31 Cf. Sonnenfels' promemoria of 7 April 1790, fol. 135r-v as well as the minutes of 26 March 1791, fol. 14v-15r, see S. WAGner, Der politische Kodex, p. 47-48 n. 23 and p. 56 n. 67.

32 HHStA Wien, Familienkorrespondenz A, Karton 26, fol. 38r: „Eure Majestät haben schon vor mehreren Jabren an Dero Länderstellen den Befehl erlassen, alle in den sogenannten Politicis und Publicis erflossenen Gesetze und Verordnungen zu sammeln."

33 HHStA Wien, Familienkorrespondenz A, Karton 26, fol. 38r-v.

34 HHStA Wien, Familienkorrespondenz A, Karton 26, fol. 43v: „... ein Gesetzbuch also, welches alle in dem Kriminal- und Civilkodex nicht einschlagenden Gegenstände, mithin hauptsächlich, was nicht sowohl 
Similar definitions of its content can be found later on during the whole working on the Political Codex, as for instance in Sonnenfels' submission of 4 June $1800,{ }^{35}$ Rottenhan's report of 29 March $1808,{ }^{36}$ Sonnenfels' report of 21 November 1808, ${ }^{37}$ Sonnenfels' comments of 27 February $1813,{ }^{38}$ and in Chotek's and Sonnenfels' report of 4 October 1813. ${ }^{39}$

With regard to the question, how the Political Codex could be achieved,
Sonnenfels suggests the establishment of a new Hofcommission after some preparatory work of roughly 18 months. ${ }^{40}$ This commission would have to provide first the order (Ordnung) as structure of the Political Codex, then - as most important task - preliminary principles (vorläufige Grundsätze or regulae directivae) for the work in substance and finally the elaboration of the code itself by including the Länderstellen. ${ }^{41}$

zum richterlichen Amte, sondern zur leitenden vorsorgenden, öffentlichen Verwaltung in ihrem ganzen weiten Bezirke gehörig ist, umfängt."

35 Sonnenfels' submission of 4 June 1800, fol. 113r-v, ed. by S. WaGner, Der politische Kodex, appendix 8, p. 303-309, 303: „... alles, was nicht in dem bürgerlichen und dem Strafgesetzbuche vorkommt, aufnebmen mithin sowobl die Verbältnisse und Verbindlichkeiten der Bürger zu dem Staate und in Ansehung der öffentlichen Vorkehrungen, als die vielfältigen Verhältnisse der Bürger unter sich, nach Stand, Beschäftigung, und den daraus entspringenden wechselseitigen Rechten und Pfichten begreifen“. - For this submission, see S. WAGNER, ibidem, p. 119-122, 120.

36 Rottenhan's report of 29 March 1808, fol. 1r, ed. by S. WAGner, Der politische Kodex, appendix 15, p. 348-353, 348: „... nach dem Muster der bürgerlichen Gesetzbücher eine vollständige, nach dem wesentlichen Zusammenhange der Gegenstände der öffentlichen Verwaltung geordnete Sammlung aller in der Ausübung stehenden Verordnungen, die nicht zum Justizfache gehören, zu Stande zu bringen." - For this report, see S. WAGNER, ibidem, p. 139-144, 139.

37 Sonnenfels' report of 21 November 1808, fol. 7r-25v, ed. by S. Wagne r, Der politische Kodex, appendix 16, p. 358-370 with a lengthy and detailed discussion. See S. WAGNER, ibidem, p. 146-148, 152-157.

38 Sonnenfels' comments of 27 February 1813, fol. 34v-35r and 45v-46r, ed. by S. WAGNER, Der politische Kodex, appendix 34, p. 472-482, 474 and 482. For these comments, see S. Wagner, ibidem, p. 188-193, 189, 193.

39 Chotek's and Sonnenfels' report of 4 October 1813, fol. 9r-v, ed. by S. Wagner, Der politische Kodex, appendix 38, p. 492-494, 493. For this report, see S. WAGner, ibidem, p. 197.

40 HHStA Wien, Familienkorrespondenz A, Karton 26, fol. 39v-40r.

41 HHStA Wien, Familienkorrespondenz A, Karton 26, fol. 40r-v: „Das erste, so bey dieser Kommission vorgetragen werden sollte, wäre die entworfene Ordnung des Kodex: Das zweyte, die vorläufgen Grundsätze, oder gleichsam die regulae directivae, nach welchen die Verordnungen und Anstalten gewählt, oder, wo sie abgängig, vorgeschlagen werden müßten. Dieß ist ohne Zweifel der wichtigste, der wesentlichste Theil, der von dem Werthe, oder Unwerthe des ganzen Werks entscheidet: weswegen die Kommission, was sie in diesem Stücke festgesetzt, vorläufig der allerhöchsten Beurtheilung zu unterwerfen hätte. Wenn diese erfolgt, so könnte zur wirklichen Bearbeitung geschritten werden, von welcher je, wie eine Hauptabtheilung vollendet wäre, das Referat bey der Kommission vorgenommen, dann aber eine Abschrift an alle Länderstellen gegeben würde, um von denselben zu vernehmen, was vielleicht nach der besonderen Verfassung, dem Lokal, u.d.g. nicht anwendbar, oder auf welche Weise, mit welchen Mässigungen es anwendbar seyn möchte, wobey gleichwohl den 
This does fully coincide with the later description of the first proposal in Sonnenfels' promemoria of 7 April 1790, ${ }^{42}$ especially with regard to the intended co-operation of the Länderstellen. ${ }^{43}$

As it emerges from the second manuscript copy Sonnenfels did afterwards have a deliberation with the Austro-Bohemian Chancellor about the different approach of his Political Codex compared with the compilation the Hofkanzlei was working on since $1768 .{ }^{44}$

As Sonnenfels reports in his promemoria of 7 April 1790, he got the full support of the Hofkanzlei. Since his proposal was finally approved, he drafted the order in which the subject-matter should find its place in the compilation (Ordnung, nach welcher die Gegenstände in der Sammlung ibren Platz haben würden), together with a broader systematic outline (Umriß) and a schedule (Tabelle) illustrating the coherence of the whole internal administration..$^{45}$

In line with Osterloh it can be supposed with reason, that Sonnenfels had in view to take his own system as a basis from the very beginning, ${ }^{46}$ because the respective schemes of 1791 and 1808 for a Political Codex do also heavily rely on his Grundsätze der Polizey, Handlung und Finanz. ${ }^{47}$ Nevertheless there is as yet no further immediate evidence known in the sources for 1780 .

Provinzialstellen zugleich die festgesetzten regulae directivae immer mitgetheilt, und in ibren Erinnerungen sich an dieselben, als unabänderliche Grundsätze zu halten, anbefohlen werden müßte."

42 Sonnenfels' promemoria of 7 April 1790, fol. 135v-136r, ed. by S. Wagner, Der politische Kodex, appendix 1, p. 237: „Mit eben derselben Offenheit wurden auch schon die Mittel angezeigt, durch welche der Zweck erreicht werden soll: Zuerst: der Entwurf einer Ordnung, nach welcher die Gegenstände in dem Kodex ibre Verbindung haben sollen. Dann, die vorläufige Bestimmung der Grundsätze, oder der Direktivregeln, nach welchen die Verordnungen und Anstalten gewählt, oder, wo sie abgängig, ersetzt werden sollten. Endlich, nach der entworfenen Ordnung und den bestimmten Grundsätzen: die wirkliche Sammlung."

43 Sonnenfels' promemoria of 7 April 1790, fol. 140v, ed. by S. Wagner, Der politische Kodex, appendix 1, p. 240: „... indem auch von dieser Seite schon in dem ersten Vortrage ausdrücklich vorgesehen war: 'Je, wie eine Abtheilung vollendet seyn würde, davon eine Abschrift an alle Länder zu geben, um von denselben zu vernehmen, was nach der besondern Verfassung, den Ortsumständen u. s. w. anwendbar, oder auf welche Weise, mit welchen Mässigungen es anwendbar seyn möchte? “

HHStA Wien, Familienkorrespondenz A, Karton 26, fol. 44r.

Sonnenfels' promemoria of 7 April 1790, fol. 136r-v, ed. by S. WAGner, Der politische Kodex, appendix 1, p. 237: „... Ich schickte mich sogleich an, den Auftrag zu befolgen, und entwarf nach der Reihe, wie ich es vorgeschlagen hatte, zuerst die Ordnung, nach welcher die Gegenstände in der Sammlung ibren Platz haben würden. Diese Ordnung war in einen umständlicher abgefaßten Umriß eingekleidet, in welchem der Zusammenhang durch die beigesetzten Ursachen deutlicher auffiel. Am Ende war noch eine Tabelle angehängt, welche die Verbindung aller Theile der inneren Staatsverwaltung anschaulich vorstellte." - See also S. Adler, Die politische Gesetzgebung, p. 93; K.-H. Osterloh, Sonnenfels, p. 206; W. Ogris, Sonnenfels als Rechtsreformer, p. 49.

46 K.-H. Osterloh, Sonnenfels, p. 206.

47 For a synopsis of Joseph von Sonnenfels, Grundsätze der Polizey, Handlung und Finanz, I-III, $5^{\text {th }}$ ed., Wien 1787, with the schemes of 1791 and 1808, see S. WAGner, Der politische Kodex, p. 219-233. 


\section{The politische Compilationshofcommis- sion under Joseph II}

\section{The set up of the politische Compila- tions-hofcommission}

At the end of the Handbillett of 25 March 1781, dealing with the establishment of a more efficient administration, ${ }^{48}$ Joseph II inquired after the progress of the Political Codex project. ${ }^{49}$ Kaunitz, too, in his preceding vote referred to this project. ${ }^{50}$ So there was quite serious interest in its development.
With regard to the following report of the Hofkanzlei of 20 April 1781 the Staatsrat by majority rejected in May 1781 the concept of a codification and recommended instead a mere law collection. As Kreßel suggested, the already prepared compilation for Bohemia should be completed and an equivalent one be started for Austria, so that loopholes in the legislation could be detected and propositions be made how to fill them. ${ }^{51}$ Hatzfeld in addition harshly criticized

48 Cf. Friedrich Walter, Die Österreichische Zentralverwaltung, II. Abt., Bd. I/2, Teil 1: Die Zeit Josephs II. und Leopolds II. (1780-1792), Wien 1950, p. 4.

49 HHStA Wien, StR-Prot. 1781/I (vol. 74), 252 ex 1781, Circul. Puncten allerhöchst $S^{\mathrm{r}}$ des Römischen Kaisers Majestät - Wie künftig die Hof-und Länderstellen zu Befolgung der allerböchsten Befeblen, und $z u$ Verrichtung ibrer Amtsobliegenheiten angewiesen werden könnten: „Billet an die Böhm. Ö. Kanzley ... 5 5 ... Im übrigen gewärtige von der Kanzley demnächstens die Anzeige, ob das Geschäft mit der Compilation des politischen Codicis, seinen Fortgang gewinne, und wie weit es mit dieser so nothwendigen Ausarbeitung schon gekommen."

50 HHStA Wien, StR-Kaunitz, Karton 3 (1777-1781), Votum 20 de 1781 (StR 252 ex 1781), ad Circul. 252 - Die Zustandbringung eines ächten Staatssystems betr.: „Die zur Staatsräthlichen Überlegung vorgelegten 4 Fragen scheinen hauptsächlich zum Endzwecke zu haben, daß in die Staatsverwaltung, so wie derselben Maschine dermal besteht (und worinnen sich verschiedene GrundMängel befinden, die nicht anders als das durch Umgestaltung des Ganzen zu heben seyn dürften) einsweilen mehrere Activität und Genauigkeit gebracht werde. Ad $1^{m}$. Setzt die Befolgung der Gesetze eine verlässige Kundmachung und genaue Aufsicht voraus. Von der erstern könnte man sich bey neuen Gesetze auf die in den StaatsRäthlichen Votis vorgeschlagene Art, und bey den alten durch die schlechterdings nothwendige auszugsweise Compilation derselben versichern, an der dem Vernehmen nach bey der Böhmischen Hofkanzley wirklich gearbeitet wird, folglich von ihr diesfalls die Auskunft könnte abgefodert werden. ..."

51 C. von Hock - H. Bidermann, Der österreichische Staatsrath, p. 124-125 give the following informations: „Löbr beklagte, daß man bereits 30 Jahre lang sich mit dem Gedanken etwas derartiges zu Stande zu bringen, trage, gleichwohl aber nicht recht wisse, was daraus werden soll. Er verwarf die Ausarbeitung eines Gesetzbuches und meinte: eine mit Vermeidung aller Widersprüche und Wiederholungen angelegte Sammlung wäre das Zweckmäßigste. Doch trug er Bedenken, eine solche Revision dem Gutdünken des H. R. Sonnenfels allein anheimzustellen; vielmehr müßte jeder von diesem zur Veröffentlichung vorbereitete Theil einer Überprüfung durch eine eigene Hofcommission unterzogen und das so richtig gestellte Elaborat jeweilen dem Kaiser zur Genehmigung seines Inhaltes vorgelegt werden. Gebler war der nämlichen Ansicht, wünschte aber außerdem die Herausgabe eines gemeinnützigen Kalenders, dem von Jahr zu Jahr die wichtigeren Gesetze und Verordnungen einzuschalten wären. Es war das eine ursprünglich vom Hofrathe Margelik ausgeheckte Idee. Kresel befürwortete den Abschluß der für Böbmen vorbereiteten Sammlung der hier geltenden Gesetze und glaubte, es werde genügen, wenn in der Zwischenzeit für die altösterreichischen Provinzen das Gleiche in Angriff genommen wird; dabei würde es 
Sonnenfels' professional qualification and personality ${ }^{52}$ - a criticism, he would repeat ten years later. ${ }^{53}$ Kaunitz took Kreßel's and Gebler's side. ${ }^{54}$

The Emperor's resolution of 9 May 1781 adopted the ideas of the Staatsrat concerning the mode of operation, but adhered to Sonnenfels' person. That means, he decreed to set up a separate commission, the politische Compilationshofcommission, ${ }^{55}$ but Sonnenfels obtained the position of the responsible referee. The Emperor further ordered to begin with the Bohemian laws and to make a comparison with the Austrian laws, to assimilate them to each other as far as possible or even to

sich auch zeigen, welche Lücken die Gesetzgebung hat, und um diese auszufüllen, könnte die mit der Arbeit zu betrauende Commission gleich Anträge formuliren, welche in der Form von Protokollen Grundlagen weiterer Berathungen würden." - See also S. AdLer, Die politische Gesetzgebung, p. 95; K.-H. OsterLOH, Sonnenfels, p. 207.

52 C. von Hock - H. Bidermann, Der österreichische Staatsrath, p. 125; S. Adler, Die politische Gesetzgebung, p. 95-96 n. 20: „Dem die Geschäftskenntnis und seinen Schriften nach zu urteilen auch die erforderliche Bescheidenheit mangle, - seiner auf Kosten der Verständlichkeit oft allzu zierlichen Schreibart nicht zu gedenken."

53 S. Adler, Die politische Gesetzgebung, p. 104; S. Wagner, Der politische Kodex, p. 63.

54 HHStA Wien, StR-Kaunitz, Karton 3 (1777-1781), Votum 53 de 1781 (StR 1003 ex 1781), Vortrag der B. O. ${ }^{\text {en }}$ Hofkanzley vom 20. April 1781 - Die höchst abverlangte Auskunft, wie weit es mit der Sammlung des Politischen Codicis gekommen sey? betr.: „ich finde den von dem Hofrath v. Sonnenfels eingereichten Plan vortreffich verfaßt, und wäre ihm also nach solchem die ganze Ausarbeitung aufzutragen. Daß diese Compilation der Gesetze für die Böhmischen von jener für die Österreichischen Länder abzusöndern, daß mit der ersten der Anfang zu machen, und mittlerweile zugleich alles nöthige wegen Sammlung der Österreichischen Gesetze zu bewerkstelligen sey, hierinfalls bin ich mit den vorstehenden Votis verstanden. Insonderheit trette ich auch dem Einrathen des Freyherrn v. Kreßl bey, daß eine besondere Commission niederzusetzen wäre, und Hofrath v. Sonnenfels hiebey über seine Arbeit zu referiren hätte. Bey dieser Arbeit kommt es nun zwar hauptsächlich nicht auf eine neue Legislation, sondern hauptsächlich darauf an, daß die bisherigen Patente und sonstige Verordnungen kurz und deutlich extrabiret und nach den vorgeschlagenen Rubriken in ein zusammenhängendes Sistem gebracht werden. Gleichwohl aber könnte Hofrath v. Sonnenfels und die hierzu bestimmte Commission bey dieser Gelegenheit weiter gehen, und dasjenige, was sie etwa bey den bestehenden Gesetzen defectuos, oder widersprechend finden dürften, jedesmal anmerken, Vorschläge zur Verbesserung machen, und hierüber das Gutachten erstatten. Was die bessere Einrichtung der Kalender betrifft, trette ich dem Voto des Freyberrn v. Gebler bey."

55 Since the commission is usually called "politische Compilations[Hof]commission" in the sources, this name appears more favourable than the term ,committee“ used by Derek BEALEs, Joseph II, vol. 2: Against the World 1780-1790, Cambridge 2009, p. 544-545.

HHStA Wien, StR-Prot. 1781/I (vol. 74), 1003 ex 1781, Circul. Vortrag der böbm. ö. Kanzley vom $20^{e n}$ April 1781 - Die Anzeige ob das Geschäft mit der Compilation des politischen Codicis seinen Fortgang gewinne, und wie weit es mit dieser Arbeit gekommen seye betr.: "Re solutio Es ist dem Sonnenfels nach seinem Plan die ganze Ausarbeitung aufzutragen: der erste Anfang kann mit der Compilation für die Böhmischen Länder, und zu gleicher Zeit alles Nöthige, wegen vorläufiger Sammlung in den Österreichischen Ländern eingeleitet werden. Man wird sodann zu Gewinnung der Zeit allemal, wie ein Gegenstand in dem Böhmischen Codice reguliret ist, selben sogleich mit den Österreichischen 
unify them. ${ }^{56}$ Thus the project of a Political Codex was not turned down in any way as Hock/Bidermann mistakenly do assert. ${ }^{57}$

\section{The first drafts of the politische Compi- lationshofcommission}

According to the informations given by Hock/Bidermann and Adler some legislative proposals concerning demographic measures were attached by Sonnenfels to his first two elaborated booklets. - What appears to be very likely considering the essential importance this matter generally had for Sonnenfels. ${ }^{58}$ These drafts were accepted during their revision in July 1781 by the majority of the commission, whereas they were rejected by the Hofkanzlei. ${ }^{59}$ In the Staatsrat the opinion was divided too: Löhr attacked Sonnenfels' action, Gebler on the contrary defended it. ${ }^{60}$ Kaunitz

Gesätzen compariren, und den Unterschied erwegen, ob nicht die gleiche Ausmessung auch allhier vollkommen oder mit kleinen Abänderungen anpassen könne. Von Seiten der Kanzley ist in dem Geschäft eine Commission zu bestellen, bey welcher Sonnenfels seine Ausarbeitung zu referiren hat. In Betreff der Kalender wird die Kanzley auf die Anmerkungen des Margelick den diensamen Bedacht nehmen. Meine Gesinnung gehet dabin, keines der dermaligen Kalender-Privilegien erneuern zu lassen, sondern auch in diesem nicht unbeträchtlichen Handlungszweige, so wie in allen andern vollkommene Freyheit, jedoch unter der nöthigen politischen Leitung fürohin zu gestatten." - See also S. AdLER, Die politische Gesetzgebung, p. 96 n. 21.

57 See also S. Adler, Die politische Gesetzgebung, p. 95 n. 19 with reason against the assertion of C. von Hock - H. Bidermann, Der österreichische Staatsrath, p. 124.

58 Cf. Joseph von Sonnenfels, Grundsätze I, §§ 25-31 and §§ 32-42; IDEM, Über das Wort Bevölkerung, in: Politische Abhandlungen, Wien 1777, p. 231-270; IDEM, Handbuch der inneren Staatsverwaltung I, Wien 1798, §§ 28-35 and $\S 36-54$. - Even in 1767 the Archbishop of Vienna Migazzi complained about the population theory of Sonnenfels, whereas the majority of the Staatsrat defended him, see C. von Hock - H. Bidermann, Der österreichische Staatsrath, p. 61-62; K.-H. Osterloh, Sonnenfels, p. 126-128; Derek Beales, Joseph II, vol. 1: In the shadow of Maria Theresa 1741-1780, Cambridge 1987, p. 476; F. Szabo, Kaunitz, p. 187-188. See also Reiner Schulze, Policey und Gesetzgebungslehre im 18. Jahrhundert, Berlin 1982, p. 101 n. 6. Frank Herdmann, Montesquieurezeption in Deutschland im 18. und beginnenden 19. Jahrhundert, Hildesheim 1990, p. 187-190 detects with regard to population policy a thorough analysis of Montesquieu's ideas by Sonnenfels. - For the general background, see Martin Funrmann, Bevölkerungsund Ehepolitik in der deutschen politischen und ökonomischen Theorie. Aufgeklärter Absolutismus und Frühliberalismus (ca 1750 - ca 1820), Zeitschrift für Neuere Rechtsgeschichte 22, 2000, p. 31-51, 33-42; IDEM, Die Politik der Volksvermehrung und Menschenveredelung. Der Bevölkerungsdiskurs in der politischen und ökonomischen Theorie der deutschen Aufklärung, Aufklärung 13, 2001, p. 243-282, 246247; IDEM, Volksvermehrung als Staatsaufgabe? Bevölkerungs- und Ehepolitik in der deutschen politischen und ökonomischen Theorie des 18. und 19. Jahrbunderts, Paderborn 2002, especially p. 59-61.

59 C. von Hock - H. Bidermann, Der österreichische Staatsrath, p. 125; S. Adler, Die politische Gesetzgebung, p. 96.

60 C. von Hock - H. Bidermann, Der österreichische Staatsrath, p. 125-126 give the following informations: „Löhr erblickte in dem Vorgehen des H. R. Sonnenfels einen Übergriff und bestritt auch das Recht der Commission, neue Gesetze zu entwerfen. Gebler fand es begreiflich und gerechtfertiget, daß Sonnenfels sowohl als die Commission es nicht beim bloßen Anzeigen bestehender Lücken bewenden ließen, sondern diese gleich auszufüllen sich anschickten." - See also S. ADLER, Die politische Gesetzge- 
likewise joined the position of Gebler. ${ }^{61}$ Joseph II resolved this report of the Hofkanzlei of 21 July 1781 on 31 August 1781 and got the facts clear, that it was not his intention to induce a new legislation in substance. ${ }^{62}$ On the contrary, the commission should confine itself to put the existing regulations into a systematic order and, in that case, to eliminate present contradictions and obscurities; if the commission feels the need for alterations or amendments, it has to submit its proposals via the Hofkanzlei to his decision. ${ }^{63}$ As already Adler is emphasizing, the existence of the politische Compilationshofcommission was consequently not questioned at this point. ${ }^{64}$

Almost ten years later Sonnenfels' promemoria of 7 April 1790 is also making out the Hofkanzlei as main opponent by quoting an extract of its report. Therein the Hofkanzlei commentating the second Kompilationsprotokoll does harshly criticize Sonnenfels' style and approach by blaming him to have exceeded his

bung, p. 96. For the closer relationship between Gebler and Sonnenfels, see Wilhelm E. WAHLbERG, Die Reform der Rechtslehre an der Wiener Hochschule seit deren Umwandlung zu einer Staatsanstalt, in: Gesammelte kleinere Schriften II, Wien 1877, p. 1-54, 35; Irene Leibbrandt, Die alten Stammbäume sind nun gefällt. Adel in der Literatur am Ende des Alten Reiches, Köln 1997, p. 40-50, 42-43.

${ }_{61}$ HHStA Wien, StR-Kaunitz, Karton 3 (1777-1781), Votum 90 de 1781 (StR 1808 ex 1781), Vortrag der B. Ö. Hofkanzley vom $21^{\text {ten }}$ Julius $1781-$ Zur Begleitung der Zwey ersten Protokollen der zur Ausarbeitung des politischen Codicis aufgestellten CompillationsCommission: „Ich sehe die ganze Sache überhaupt vollkommen so wie der Freyherr v. Gebler an, und bin aus den von demselben angeführten Gründen mit dessen Voto gänzlich verstanden."

62 Wilhelm Brauneder, Zeitschrift für Neuere Rechtsgeschichte 28, 2006, p. 483-485, is overstressing the point. Contrary to his view the possibility for some alteration or innovation is not denied at all by S. WAGner, Der politische Kodex, p. 35 whose interpretation does concur with S. AdLer, Die politische Gesetzgebung, p. 97 and K.-H. Osterloh, Sonnenfels, p. 207.

63 HHStA Wien, StR-Prot. 1781/II (vol. 75), 1808 ex 1781, Circul. Vortrag der Böhm. Ö. Kanzley de dato 21. Julii 1781 - Mit Überreichung der 2 ersten Protokollen der zu Ausarbeitung des allgemeinen politischen Codex aufgestellten CompilationsHofcommission: „R esolutio Über das erste Protokoll begnehmige lediglich das Einrathen. Bey dem zweyten Protokoll: ist der Sinn Meiner ertheilten Anordnung, da Ich den vorgelegten Sonnenfelsischen Plan in der guten Eintheilung der Materie und der Art der Abfassung dieses Codicis genehm gehalten, dahin nicht gerichtet gewesen, eine ganz neue Legislation zu veranlassen, sondern die Compilations-Commission hat sich bey diesem aufgetragenen Geschäfte bloß in den Schranken zu halten, die bisherigen Patenten und Verordnungen nach den wobl entworfenen Rubriken in ein zusammenhängendes System zu bringen, dieses kurz und deutlich in einem Codicem zusammenzufassen, die bisherigen Anordnungen und Generalien zwar allerdings von Widersprüchen und Undeutlichkeit zu reinigen, jedoch keine neue Legislation zu entwerfen. Sollten gleichwoblen in der Verhandlung solche Gegenstände vorkommen, bey denen die Commission auf jenem, was die bisherigen Anordnungen vorschreiben, nicht zu beharren, sondern eine Änderung einzubringen für nöthig fände, oder sollte dieselbe auch in der bisherigen Gesetzgebung ein oder anderes nicht gänzlich erschöpfet, mithin auf eine neue bestimmte Anordnung noch anzutragen erachten, so muß in jeglichem derley Fall dasjenige, was vorgeschlagen wird, mit einem besonderen Gutachten durch den Weg der Böhm. Öst. Kanzley zu Meiner Schlußfassung vorgelegt werden." - See also S. Adler, Die politische Gesetzgebung, p. 96-97 n. 24. K.-H. Osterloh, Sonnenfels, p. 207 dates the Emperor's resolution on 21 July 1781, but this is actually the date of the Hofkanzlei's report.

S. Adler, Die politische Gesetzgebung, p. 97. 
competences as referee, as he did not only collect the existing regulations, but also checked them in substance and made even propositions for new laws. Above all, however, the Hofkanzlei is warning, that a shock of the state to its very foundation has to be feared, since the propositions show no consideration for the constitutional differences of the provinces (Verschiedenheit der Länderverfassungen). ${ }^{65}$ These informations given by Sonnenfels about this report of the Hofkanzlei do im- prove the state of sources, but one cannot assess with definite certainty, whether this actually should be the report of 20 April 1781 (resolved on 9 Mai 1781) ${ }^{66}$ or more likely - the one of 21 July 1781 (resolved on 31 August 1781 ${ }^{67} .{ }^{68}$ However, Sonnenfels is in retrospective repeatedly complaining about this ,intrigue" of the Hofkanzlei, not only in his promemoria of 7 April 1790, ${ }^{69}$ but also in his submission of 22 July $1790 .{ }^{70}$ Moreover the minutes of 26 March 1791 do explicitly blame

65 Sonnenfels' promemoria of 7 April 1790, fol. 138r-139r, ed. by S. WAGNER, Der politische Kodex, appendix 1, p. 239: „Die damalige Hofkanzley ward gleichwobl durch diese Zurückhaltung nicht irre geführt: und da ibre Grundsätze bereits von dem Anstosse der Umstände eine neue Richtung erbalten $z u$ haben schienen, begleitete sie das Kompilationsprotokoll mit einem Vortrage, von dem ich mir die Beweggründe zu errathen untersage, und bloß das Wesentlichste des Inhalts ausziehe. Sie stellte vor: 'durch das zweyte Kompilationsprotokoll werde beinahe ganz von der vorschriftmässigen Behandlungsart abgegangen, und gerade dem Zwecke entgegen gearbeitet, als der sich bloß auf die Sammlung der schon bestehenden Verordnungen beschränke, da bier mit Vorbeigehung und Hinweglassung derselben von dem Referenten auf neue Gesetze Anträge gemacht würden. Diese Anträge selbst aber, bei denen auf die Verschiedenheit der Länderverfassungen, Verträge, und ständischen Vorrechte gar nicht zurückgesehen werde, seyen von der äussersten Bedenklichkeit und liessen die Erschütterung und den Umsturz der Grundverfassungen der Länder, und selbst für den ganzen Staat die gefährlichsten Folgen besorgen. Überhaupt beschäftige sich der Referent größten Theils mit weitwendiger Kritisirung der schon eingeführten Gesetze, statt deren nach seinem Vorschlage neue von ihm erfundene eintreten sollen. Er verliere sich in unnöthigen Räsonnements und weitläuftigen Erörterungen theoretischer auf die Länderverfassung gar nicht anwendbarer Sätze, die mehr zur Schule, als einer Dikasterialbehandlung gehörten. Sollte nun auf diese Art weiter fortgefahren werden, so würde die Ausarbeitung des Werkes $z u$ lange verzögert, da gleichwohl dessen möglichste Beförderung und Vollendung zum nothwendigen Augenmerke genommen werden müsse, um das Publikum der Wohlfahrt einer politischen Sammlung, der es mit so vieler Sehnsucht entgegen sehe, sobald als möglich theilhaft zu machen." - See also S. AdLER, Die politische Gesetzgebung, p. 94; K.-H. Osterloh, Sonnenfels, p. 207.

See above, n. 56.

67 See above, n. 63.

68 S. Adler, Die politische Gesetzgebung, p. 95 ranges these statements prior to May 1781, so that they would to be attributed to the report of 20 April 1781 . On the other hand, the fact, that Sonnenfels' promemoria does shortly after this passage quote the resolution of 31 August 1781, and the use of the term „Protokoll“ argue rather in favour of the report of 21 July 1781.

69 Sonnenfels' promemoria of 7 April 1790, fol. 139r-141r, ed. by S. WaGner, Der politische Kodex, appendix 1, p. 240.

70 HHStA Wien, Vertrauliche Akten, Karton 41 (alt 62), № 16, Nota von Hofrath Sonnenfels an S. M. den 22. Juli 1790 überreichet - über welche er alsogleich eine Entscheidung haben wollte, die seinen 
the former Austro-Bohemian Chancellor Blümegen to have obstructed the further realization of this project. $^{71}$

Furthermore is to mention, that at this time Sonnenfels started to give lectures on Geschäftsstil. ${ }^{72}$ In addition he drafted, as directed by Joseph II, guidelines for the style and correspondence of authorities, until he finally was charged with the stylistic checking of any newly issued legislative act (,jeden hinausgehenden patentes, so viel den styl beträfe "). ${ }^{73}$

In the Handbillett of 13 April 1782 Joseph II had inquiries made by the
Hofkanzlei, how far Sonnenfels already made progress with his excerpt of the political regulations to deal with respectively till when the actual elaboration could be accomplished. ${ }^{74}$

According to Hock/Bidermann the following report of the Hofkanzlei held out a prospect of a mere excerpt for the use of the public servants. The majority in the Staatsrat nevertheless insisted on the original plan and recommended to terminate the collection with the year $1782 .{ }^{75}$ Kaunitz followed in his vote the views of Kreßel and Hatzfeld. ${ }^{76}$

Charakter und seine Denkungs Art entwickelt, fol. 356-363, 357v note *: „Der Aufsatz, den ich Eurer Majestät über die politische Kompilation übergeben habe, liefert ein Beyspiel, daß selbst die Hofstelle sich $z$ u diesem Kunstgriffe erniedriget, um einen schon genehmgehaltenen Vorschlag zu vereiteln."

71 Minutes of 26 March 1791, fol. 15r-v, ed. by S. Wagner, Der politische Kodex, appendix 2, p. 247.

72 Cf. Joseph von Sonnenfels, Versuch über die Grundsätze des Stils in privat und öffentlichen Geschäften, 2 Theile, Wien 1781; IDEM, Über den Geschäftsstil. Die ersten Grundlinien für angehende österreichische Kanzleybeamten, Wien 1784. - See K.-H. Osterloh, Sonnenfels, p. 236; S. Karstens, Sonnenfels, p. 94-95.

73 F. Walter, Die Österreichische Zentralverwaltung, II. Abt., Bd. I/2, Teil 1, p. 3 n. 6; K.-H. OsterLoH, Sonnenfels, p. 236-238; S. Karstens, Sonnenfels, p. 227-229. Even in 1771 Sonnenfels had postulated a clear legal language, cf. Joseph von Sonnenfels, Ueber die Liebe des Vaterlandes, Wien 1771, p. 52-73 („IV. Hauptstück: Vortheile zur Verbreitung der Vaterlandsliebe in den Gesetzen“); see Wilhelm Brauneder, Gesetzeskenntnis und Gesetzessprache in Deutschland von 1750 bis 1850 am Beispiel der Habsburgermonarchie, in: Studien I, Frankfurt am Main 1994, p. 519-543, 524, 528533; for Sonnenfels' concept of patriotism, see Ernst Wangermann, Joseph von Sonnenfels und die Vaterlandsliebe der Aufklärung, in: Das achtzehnte Jahrhundert und Österreich 2, 1985, p. 41-42; IDEM, Joseph von Sonnenfels und die Vaterlandsliebe der Aufklärung, in: Helmut Reinalter (ed.), Joseph von Sonnenfels, Wien 1988, p. 157-169; Harm Klueting, 'Bürokratischer Patriotismus'. Aspekte des Patriotentums im theresianisch-josephinischen Österreich, Aufklärung 4/2, 1989, p. 37-52, 41-45; Reinhard Stauber, Vaterland-Provinz - Nation. Gesamtstaat, Länder und nationale Gruppen in der österreichischen Monarchie 1750-1800, Aufklärung 10/2, 1995, p. 55-72, 68-71.

74 HHStA Wien, StR-Prot. 1782/I (vol. 78), 1065 ex 1782, 'Circul. Nota des N. Ö. ViceStatthalters Grafen von Herberstein de dato 2. April 1782 - Über die Vorstellung eines Anonimi wegen der schlechten Polizey- und Sicherheitsanstalten auf dem Land: ,Resolutio Billet an die B. Ö. Kanzley ... Von der Kanzley gewärtige Ich übrigens die Auskunft nach vorläufiger Vernehmung des Sonnenfels, wie weit er mit dem ihm aufgetragenen Auszuge der politischen Anordnungen gekommen sey, auch wann er mit seiner Arbeit fertig zu werden gedenke? wobey ibm zugleich aufgetragen werden kann, einen Theil des schon zu Stande gebrachten zur Einsicht vorzulegen."

75 C. von Hock - H. Bidermann, Der österreichische Staatsrath, p. 126 give the following informations: „Allein im April 1782 gab eine Erkundigung des Kaisers nach dem Stande der Sonnenfels'schen Arbeit zu 
Hence the Emperor's resolution of 31 May 1782 determined the end of the year 1782 as terminum ad quem for the collection of regulations; at the same time Sonnenfels was instructed to deliver an opinion, how this work could be achieved in the best way. ${ }^{77}$

According to Adler Sonnenfels thereupon promised a register until the end of the year 1782 and the actual Codex within four and a half years. ${ }^{78}$

Facing this answer the positions in the Staatsrat were discordant. Martini supported Sonnenfels provided, however, that further assistance should be called in, if Sonnenfels was unable to keep the term for deliverance of the excerpt. Hatzfeld moreover generally questioned the feasibility of the project; in doing so he focused on the constitutional differences within the parts of the monarchy, which would render the setting up of a Codex politicus even more difficult as the current establishment of the Codex civilis. ${ }^{79} \mathrm{Kau}^{-}$

Erörterungen Anlaß, welche das Geständnis hervorriefen, daß Sonnenfels planlos nur diejenigen Materien bearbeite und abschließe, von welchen er meint, daß der Kaiser sie bei sich als abgeschlossen betrachte. Die böhm.-österr. Hofkanzlei und die mehrerwähnte Commission entschuldigten dieses Vorgehen mit der Unfertigkeit der Gesetzgebung und bezeichneten einen kurzen Auszug zum Gebrauche der Beamten als das, was nun vor Allem noth thue. Gebler trat dieser Ansicht bei; die übrigen Mitglieder des Staatsrathes aber drangen auf die Durchführung des früher Beschlossene und riethen, die Sammlung mit dem Jahre 1782 abzuschließen."

76 HHStA Wien, StR-Kaunitz, Karton 4 (1782-1783), Votum 168 de 1782 (StR 1642 ex 1782), 'Vortrag der B. Österr. Hofkanzley vom $18^{\text {ten }}$ May 1782 - Die allergdgst. abverlangte Auskunft, wie weit der Hofrath von Sonnenfels mit dem Ibm aufgetragenen Auszuge der politischen Anordnungen gekommen sey betr.': „Ich bin ad $1^{\text {mum }}$ et $2^{\text {dum }}$ mit dem ersten, ad $3^{\text {tium }}$ mit dem Voto des Freyh. $v$. Kreßl und der weiteren Erinnerung des $H$. Grafen v. Hatzfeld vollkommen verstanden."

77 HHStA Wien, StR-Prot. 1782/II (vol. 79), 1642 ex 1782, Circul. Vortrag der Böhm. Ö. Kanzley de dato 18. May 1782 - Die Auskunft, wie weit der Hofrath v. Sonnenfels mit dem ihm aufgetragenen Auszug der politischen Anordnungen gekommen seye, Betr: „Resolutio Ad $1^{m}$ et $2^{m}$ beangenehme das Einrathen der Kanzley. Ad $3^{\text {tium }}$ Muß alsogleich mit der Sistematischen Sammlung der Generalien, Patenten und Circularien zu Werke gegangen, und das Ende des heurigen Jahres einsweilen zum terminum ad quem bestimmet, hiebey aber die vorzügliche Rücksicht darauf genommen werden, womit hierinn alle jene alten Verordnungen, welche von Zeit Meiner angetrettenen Regierung abgeändert worden, gänzlich hindanngelassen werden. Wie jedoch diese Arbeit am leichtesten und besten zu Stande zu bringen? darüber muß allem bevor noch der v. Sonnenfels mit seinem Gutachten vernommen werden."

S. Adler, Die politische Gesetzgebung, p. 97 n. 25; K.-H. Osterloh, Sonnenfels, p. 207.

S. Adler, Die politische Gesetzgebung, p. 97 gives the following informations: „Freiherr von Martini sprach sich für das Anerbieten des Sonnenfels aus, aber mit dem Zusatze, daß, wenn Sonnenfels den Termin für die Ablieferung des Auszuges nicht einhalten sollte, der bisherige Bearbeiter des Auszuges der böhmischen Gesetze zur Ergänzung seiner Arbeit aufzufordern sei. Graf Hatzfeld meinte, der Endzweck der Arbeit des Sonnenfels sei, dem Publikum in möglichst kurzem Begriff alles vorzulegen, was seit Maria Theresia anbefohlen und nicht abgeändert wurde, nicht aber, daß ein dem Codici civili gleicher Codex politicus herausgegeben werde, welcher so wie ersterer alle streitbaren Gegenstände erledigt, alle politischen Gegenstände durch die Gesetzgebung erschöpfe; eine solche Arbeit würde besonders wegen Verschiedenheit der Länderverfassungen die Vernehmung aller Gubernien und Stände erfordern, und in der Ausführung noch beschwerlicher als der Codex civilis werden." - Cf. also C. von Hock - H. Bidermann, Der österreichische Staatsrath, p. 126: „.. obschon Hatzfeld sich diese Gelegenheit nicht entgehen ließ, den 
nitz supported Martini's and Hatzfeld's arguments. ${ }^{80}$

As a consequence Joseph II turned down in the resolution of 16 November 1782 the Political Codex project in its original design. The reasoning of the decision mainly referred to the risk, that within the period of four and a half years, which was estimated for the treatment of the laws passed until 1782, probably two thirds of the regulations could be superseded in the meantime. Instead of a Code, which has become already obsolete by the time of its appearance, it would be better to draw up a register of regulations and instructions for the authorities' use. ${ }^{81}$

\section{The decline of the politische Compilationshofcommission}
After that the politische Compilations- hofcommission dealt with this newly defined aim in its minutes of 18 February 1783, submitted by the Hofkanzlei with report of 6 March 1783. As it emerges from Kaunitz' corresponding vote, the commission likely expressed doubts, that not all relevant regulations were sufficient- ly published and even the collections of the authorities could not claim complete- ness. A register alone would be of no use, if there is no reliable work of reference available to consult the regulations in full length. Instead of a mere register on the one hand or a scientifically drafted

H. R. Sonnenfels der Anmaßung zu zeiben und Martini es gerathen fand, den Concipisten Kröhny mit der einstweiligen Fortführung der von ibm begonnenen Repertorien bis zum Jahre 1782 zu betrauen."

80 HHStA Wien, StR-Kaunitz, Karton 4 (1782-1783), Votum 357 de 1782 (StR 3838 ex 1782), Vortrag der Böhmisch Österreichischen Hofkanzley de dato 8. Nov. 1782 - Womit die Äusserung des HofRaths von Sonnenfels wegen des ihm aufgetragenen Auszuges der politischen Anordnungen allerunterthänigst vorgelegt wird: „ich bin überhaupt mit dem Voto des Freyherrn v. Martini verstanden. obgleich vor Erledigung der ganzen Haupt Compilation von dem Concipisten Krohny nicht wohl eine ganz vollständige und verläßliche Arbeit geliefert werden kann, so werden doch seine Auszüge inzwischen für das Publicum immer von Brauchbarkeit seyn, auch dem v. Sonnenfels zu Erleichterung seiner eigenen Arbeit dienen. Den übrigen Erinnerungen des Herrn Grafen v. Hatzfeld trette ich gleichfalls bey." See also S. AdLer, Die politische Gesetzgebung, p. 98.

81 HHStA Wien, StR-Prot. 1782/III (vol. 80), 3838 ex 1782, Circul. Vortrag der Böhm. Österr.

Kanzley de dato 8. Novembris 1782 - Womit die Äußerung des Hofrathes von Sonnenfels wegen des ihm aufgetragenen Auszuges der politischen Anordnungen vorgelegt wird: „Resolutio Das einstigste, was man von dieser Sammlung zu erwarten hat, oder wünschen kann, ist, daß die Gubernia, Kreißämter und Dominien je eher je besser nur eine Art Register bekommen, in welchem die zu verbleiben habende Patente und Befehle zum Nachschlagen in allen politischen Fällen sich versammelt finden. Dieses Register muß so eingerichtet werden, daß in selbem wohl combiniret werde, daß die Gesetze, so durch spätere Verordnungen entweder gänzlich aufgehoben, oder anderst modificiret worden, gänzlich ausgelassen oder schon verändert angesetzet werde. Diese Art Register ist das einzige Nutzbare und Gemächliche, so man von dieser ganzen Arbeit zu erwarten hat; also ist an selbem mit allem Eifer Hand anzulegen, und kann auch diese Ausarbeitung nicht lange Zeit brauchen. Das Gesetzbuch also hat vollkommen auszubleiben, da nur um bis ad terminum ad quem von Anno 1782 fertig zu werden 41/2 Jahr gebrauchet, und in diesen Jahren vielleicht 2/3 deren mühsam im Gesetzbuch colligirten und bestimmten Gesetzen wieder abgeändert worden seyn dürften, wodurch also dieses Buch bey seiner Erscheinung schon falsch und unnütz seyn würde. “- See also S. Adler, Die politische Gesetzgebung, p. 98; K.-H. Osterloh, Sonnenfels, p. 207-208; Henry E. Strakosch, State Absolutism and the Rule of Law. The Struggle for the Codification of Civil 
compilation on the other a compromise settlement in between would be more favourable for that reason. Kaunitz pleaded for this middle course as well. ${ }^{82}$

Also Joseph II settled on this third intermediate proposition in his resolution of 15 March 1783. After all a compilation was now on the agenda again, although in a modified way and manner compared with the original design of a Political Co- dex. This compilation should not contain any regulation meanwhile superseded and should be issued by a publisher. ${ }^{83}$

When Leopold, the brother and later successor of Joseph II, stayed in Vienna in July 1784, Sonnenfels presented him a system and "plan for the Political legislation“. Since this plan itself is still unknown, one can only speculate about its content and structure. $^{84}$

Law in Austria 1753-1811, Sydney 1967, p. 178; Heinrich Sтraкоsch, Privatrechtskodifikation und Staatsbildung in Österreich (1753-1811), München 1976, p. 67.

82 HHStA Wien, StR-Kaunitz, Karton 4 (1782-1783), Votum 69 de 1783 (StR 871 ex 1783): Vortrag der vereinigten B. Ö. Hofkanzley de dato 6. März 1783 - Womit das Protokoll der politischen CompilationsHofCoon vom 18. Februar wegen des statt des zu unterbleiben habenden politischen Gesetzbuchs zu verfassenden Registers zum Nachschlagen mit vollkommenen Beytritte vorgelegt wird: „der erste Vorschlag und der nach denselben eingerichtete Entwurf A scheinet zwar dem Buchstablichen Inhalt der Allerhöchsten Resolution am meisten gemäß zu seyn. Allein diese Resolution fordert ein Register zum Nachschlagen, das ist, wenn ich den Sinn derselben wohl verstehe, eine kurze Anzeige, daß über diese oder jene Materie diese oder jene Verordnung existire, welche bey vorkommenden Fällen in dem gedruckten oder geschriebenen Original nachgeschlagen, das ist in extenso eingesehen werden soll. Nun wird aber in dem Protokoll die Erinnerung gemacht, daß die nachzuschlagenden Verordnungen theils nicht gemein gemacht, theils nur in sehr kostbaren, oder selten gewordenen oft beynahe ganz vergriffenen Sammlungen zu finden sind, und daß es mit Grunde bezweifelt werden könne, ob selbst in irgend einer öffentlichen Registratur eine vollständige Gesetzsammlung anzutreffen sey. Dieses vorausgesetzt würde zwar der erste Vorschlag den Buchstaben der Allerhöchsten Resolution erfüllen, keineswegs aber dem Sinn und dem Endzwecke derselben entsprechen, denn was sollte ein Register zum Nachschlagen nützen, wenn man in mehrern Fällen das nachzuschlagende exhibitum nicht bey Handen hat? Eben diese Betrachtungen überzeugen mich dahero, daß der abgezielte Allerhöchste Endzweck nicht sicherer zu erreichen, und zugleich die Lücke der ganz abgehenden oder sehr selten gewordenen Verordnungen nicht vollständiger auszufüllen seyn dürfte, als durch die in dem dritten Vorschlage angetragene Compilation, die zwar im Styl weniger rein und in der sistematischen Ordnung weniger scientifisch als die zweyte Art der Compilation ausfallen, in der Hauptsache aber desto zuverläßlicher, gemeinnütziger und der Allerhöchsten Absicht gemäser seyn wird."

83 HHStA Wien, StR-Prot. 1783/I (vol. 82), 871 ex 1783, Circul. Vortrag der B. Ö. Kanzley de dato 6. März 1783 - Über ein Protokoll der politischen CompilationsCoon vom 18. Febr. a. c.: „Resolutio Ich begnehmige, daß nach dem dritten Vorschlag die Sammlung gefasset, und angetragenermaßen durch einen Verleger herausgegeben werde. Es sind aber nicht nur die wirklich abgeschafte Anordnungen, sondern auch jene, die zur Beobachtung gar nicht mehr gehören, oder durch entgegengesetzte Entscheidungen oder Befehle gehoben worden sind, binwegzulassen, damit dadurch nichts unnützes oder überflüssiges in der Sammlung erscheine." See also K.-H. Osterloh, Sonnenfels, p. 208 n. 13.

84 HHStA Wien, Familienarchiv, Sammelbände, Karton 16, Relazione del viaggio e soggiorno fatto da S. A. R. in Vienna nel Luglio 1784, p. 601-602: ,Allegato di N 23 - Si danno parimente annessi un Progetto, e Sistema stato presentato a S. A. R. dal Consiglier Sonnenfels sopra un piano di Legislazione Politica, che si da sotto $N^{\circ}$ 23. Il predetto Consigliere è ora in poco credito, ed è unicamente impiegato per tradurre in buono stile Tedesco tutte le Leggi, e Editti, che escono." - For the contacts between Sonnenfels and Leopold in Vienna 1778/79 and 1784, see S. WAgner, Der politische Kodex, p. 42-44. 
In the following years there are still signs for the commission's existence. In October 1783 the commission and its referee Sonnenfels drafted an instruction for the district commissioners' tours of inspection (,über die Art, wie die KreisCommissarien bey Bereisung eines Kreises oder Bezirkes fürzugehen hätten"). ${ }^{85}$ In 1785 there is again a reference to the politische Compilationshofcommission and its task, the compilation (Sammlung der Gesetze), in the Emperor's resolution of 9 September 1785 (concerning a Hofkanzlei's report of 20 August 1785). ${ }^{86}$

As Kopetz is imparting in August 1807 , this compilation finally did appear in several booklets from 1784 till 1787. It was, however, only destinated for the authorities' internal use and covered solely the years $1780-1784 .{ }^{87}$ Also Baldacci refers in his report of 1 September 1802 to this "secret compilation“ (,geheime Sammlung“). ${ }^{88}$

\section{Conclusion}

The first serious attempt to create a Political Codex under Joseph II did not miscarry at any rate due to the Emperor. Quite on the contrary he had defended Sonnenfels' project several times against resistance in the Staatsrat and the Hofkanzlei. Only the poor chances to obtain within a reasonable space of time a really workable result, induced Joseph II in the resolution of 16 November 1782 to turn down the original aim of a Political Codex and to content himself with a register instead. But already in his resolution of 15 March 1783 he moved away from a mere register and, as a compromise settlement, put in hand a compilation again, although differing from the original Political Codex project.

Karstens' view that Joseph II seemed to have been interested only in the practical outcome and not in the general importance of a Political Codex ${ }^{89}$ appears too onesided. First, it does not take into account the compromise settled by the

85 K.-H. Osterloh, Sonnenfels, p. 239 with further references. This instruction came into force for Bohemia on 11 March 1784, see Ignaz BeIdTEL, Geschichte der österreichischen Staatsverwaltung 1740-1848, vol. I, Innsbruck 1896, p. 322, 459-469.

86 HHStA Wien, StR-Prot. 1785/III (vol. 93), 3647 ex 1785, Circul. Vortrag der Böhm. Österr. Kanzley de dato 20. Aug. 1785 - Wegen Verminderung der Schreibereyen und Erweiterung der Aktivität der Länderstellen: „Resolutio Ad $1^{m}$ a. Hat es lediglich bey jener Vorschrift zu verbleiben, nach welcher die politische CompilationsCommission die Sammlung der Gesetze zu machen angewiesen worden ist, nur muß selbe kürzer, klärer, und wobl überlegt werden...."

87 Wenzel G. Kopetz, Österreichische politische Gesetzkunde, 1/1, Wien 1807, Vorerinnerung, without pagination: „Diese Sammlung ist bloß unter die Staatsbeamten vertheilt worden, und niemahls in den Buchhandel gekommen; sie ist bey Trattnern 1784-1787 in 4to gedruckt, und reicht vom Regierungsantritte Josephs II. bis zum Schluße des Jahres 1784." See also K.-H. Osterloh, Sonnenfels, p. 208.

88 Baldacci's report of 1 September 1802, fol. 92r-v, ed. by S. WAgner, Der politische Kodex, appendix 9, p. 310-321, 317. For this report, see S. WAgner, ibidem, p. 128-133, 131.

S. Karstens, Sonnenfels, p. 449. 
Emperor's resolution of 15 March 1783. Secondly, no government at any time in any place would have spent four-and-ahalf-years' work for a legislative act, which is by two-thirds already outdated by the time of its appearance due to alterations in the meantime. Therefore Beales is getting to the heart of the matter when he emphasizes that Joseph ,was determined to press ahead with reform. He made changes at a great pace and was certainly not going to await the report of a codification committee before". ${ }^{90}$ In other words, Joseph II wanted to go on and have free hand for his ad hoc reform legislation.

On the one hand Joseph's reform legislation was still in progress and had not yet reached the degree of maturity for a codification (Kodifikationsreife). On the other hand Joseph was not the type to bind himself and his reforms on fixed general principles, as his brother Leopold might have been inclined to do. ${ }^{91}$ So neither the legislation in the field of public law nor its principles could be laid down in a Political Codex in the 1780ies.

Thus the politische Compilationshofcommission had even problems to catch up with the speed of Joseph's legislation and to produce the decreed compilation. As Sonnenfels argues retrospectively in 1790 , the lack of guiding principles compelled the commission to stop its activity, since afterwards the multitude and desultoriness of the (Josephine) legislation rendered it impossible to provide a compilation consistent in substance and systematically structured. ${ }^{92}$ Instead, as Sonnenfels complains in addition, private collections of law had seized the field, but without any system and coherence, so that their voluminous tomes would contain more regulations superseded in the meantime than such still in force. ${ }^{93}$

However, the Austrian approach to codify private, criminal and public law separately has implications to the very present day. Whereas the Prussian

90 D. Beales, Joseph II, vol. 2, p. 545.

91 For the reinforcement of the Political Codex project by Leopold II, see S. Wagner, Der politische Kodex, p. 44-66.

92 Sonnenfels' promemoria of 7 April 1790, fol. 142r-v, ed. by S. WAGner, Der politische Kodex, appendix 1, p. 241: „Die bald darauf erfolgte Menge, der beständige Wechsel, die Änderungen, Wiederänderungen und Erläuterungen der Verordnungen und Vorkehrungen sind für die Kompilationskommission die geltendste Rechtfertigung, daß sie mit einer Sammlung eingehalten, wo das folgende Heft, was in dem vorhergegangenen aufgenommen werden, größten Theils wieder ausser Kraft gesetzt haben würde." - See also S. Adler, Die politische Gesetzgebung, p. 98.

93 Sonnenfels' promemoria of 7 April 1790, fol. 142v-143r, ed. by S. WAGner, Der politische Kodex, appendix 1, p. 241: „Die Gewinnsucht bemächtigte sich bald darauf des verlassenen Gebietes, und raffte obne Wabl, obne Ordnung, ohne Verbindung zusammen, was die Fruchtbarkeit der Gesetzgebung mit solchem Übermasse anbot. Das Publikum kaufte unter verschiedenen Benennungen immer einerley, und erbielt in dicken Bänden meistens mehr Verordnungen, die schon wieder aufgehoben waren, als noch bestanden." See also S. Adler, Die politische Gesetzgebung, p. 98-99; K.-H. Osterloh, Sonnenfels, p. 208 considering this remark with reason as an allusion to Kropatschek's collections of law. For the contemporary private collections of law, see S. WAGner, Der politische Kodex, p. 18-19. 
Allgemeines Landrecht (ALR) of 1794 by combining private, criminal and public law came out of date very soon, the Austri- an Allgemeines Bürgerliches Gesetzbuch (ABGB) of 1811 is still in force today having celebrated its bicentennial. ${ }^{94}$

94 See Wilhelm Brauneder - Elisabeth Berger (edd.), Österreichs Allgemeines Bürgerliches Gesetzbuch (ABGB). Eine europäische Privatrechtskodifikation, I-III, Berlin 2010; Constanze Fischer-Czermak and others (edd.), Festschrift 200 Jahre ABGB, I-II, Wien 2011; Heinz Barta and others (edd.), Kontinuität im Wandel. 200 Jahre ABGB (1811-2011), Innsbruck 2012; Barbara Dölemeyer - Heinz Mohnhaupt (edd.), 200 Jahre ABGB (1811-2011). Die österreichische Kodifkation im internationalen Kontext, Frankfurt am Main 2012. 


\section{Stephan Wagner}

\section{Politický kodex Josefa II.}

Kromě kodifikace soukromého a trestního práva vznikl v Rakousku na přelomu 18. a 19. století i projekt kodifikace veřejného práva, tzv. Politický kodex (Politischer Kodex). Podle plánů Josefa von Sonnenfelse měl pokrýt celou oblast veřejné správy. Práce začaly kolem roku 1780 a s přestávkami pokračovaly až do roku 1818, avšak neskončily úspěšně. Studie se soustředí na ranou fázi projektu v době Josefa II. v osmdesátých letech 18. století a na otázku panovníkova postoje k projektu. Po retrospektivním ohlédnutí k době Marie Terezie následuje zevrubný rozbor složení komise pro vypracování Politického kodexu roku 1781. Poté analyzuje první náčrty komise a nakonec její úpadek za vlády Josefa II. Závěrem studie končí zamyšlením nad důvody selhání politického kodexu v této epoše.

KEY WORDS:

Joseph II; Austrian Enlightenment; codification; public law; Political Codex (Politischer Kodex); Joseph von Sonnenfels 